\title{
The intellectual property of content published in virtual campuses: what legal and technological aspects should be considered?
}

\section{La propiedad intelectual del contenido publicado en los campus virtuales: ¿qué aspectos legales y tecnológicos se deben tener en cuenta?}

\author{
Carina Soledad González-González \\ Universidad de La Laguna. España \\ cjgonza@ull.edu.es \\ Luis Fajardo López \\ Universidad de La Laguna. España \\ lfajard@ull.edu.es \\ Dulce María Cairós Barreto \\ Universidad de La Laguna. España \\ dcairos@ull.edu.es
}

\begin{abstract}
Resumen
Actualmente, todas las universidades tienen plataformas de teleformación (LMS) para apoyar su docencia presencial o brindar titulaciones a distancia o semipresenciales. Estas plataformas se conocen como Campus Virtuales. Los Campus Virtuales de las instituciones educativas se han ido convirtiendo paulatinamente en repositorios institucionales de contenido educativo. El contenido que alojan dichos campus virtuales es principalmente material de apoyo docente producido por el propio profesorado universitario para el alumnado de la misma institución, y el acceso está restringido a la comunidad universitaria. Asimismo, las universidades están legalmente obligadas a tener repositorios de contenidos digitales en abierto y a difundir en abierto su producción académica financiada con fondos públicos. Sin embargo, las entidades de derechos de autor reclaman a las universidades el pago de dichos derechos, alegando que existe infracción en la publicación de contenidos digitales para uso docente en los campus virtuales. Al existir millones de recursos educativos publicados por el profesorado y por el alumnado en las aulas virtuales, actualizándose permanentemente, se hace materialmente imposible su revisión y control por parte de los servicios universitarios responsables, y por ello, las entidades de gestión piden el pago de una "cuota", no de los materiales publicados que están realmente protegidos con copyright. Por ello, en este trabajo presentamos un análisis del marco legal de los derechos de autor y la propiedad intelectual de los contenidos digitales de las universidades, especialmente para el contexto español, así como distintas soluciones tecnológicas que permiten promover el acceso abierto a los contenidos. En particular, se presenta el caso de la Universidad de La Laguna, y las acciones que se han llevado a cabo en este sentido, incluyendo un desarrollo tecnológico para Moodle que permite identificar el contenido publicado por el profesorado en las aulas virtuales y los derechos sobre los mismos.
\end{abstract}

\section{Palabras clave}

Propiedad intelectual, derechos de autor, campus virtuales, recursos educativos en abierto 


\begin{abstract}
Nowadays, all universities has learning management systems (LMS) to support their academic offer, for traditional, distance, or blended learning modalities. These LMS platforms are known as Virtual Campuses, and they have been transforming progresivelly in institutional repositories of educational digital content. Content accommodated in the virtual campuses is, mainly, educational resources produced by teachers from the university and for students of the same university, and, the access is restricted to the own university community. Besides, universities are obliged to have open digital content repositories and to broadcast their academic production supported by public fundings. However, the autor rignts' entities claim to universities the payment of copyrights, adducing that there is an infraction for teaching use in the virtual campuses. But, the millions of educational resourses published by teachers and students in the virtual campuses, and continuasly updating, make implosible the control by any institutional service. So,the copyrights entities ask fot the payment of a fee, not for the actually protected resources, but just according the size of the institution. For this reason, in this work we present an analysis of legal framework on autor rights and intelectual property of digital contents at universities, in particular, into the Spanish context. Moreover, we present different technological solutions which allows to promote the open access in universities. In particular, we present the case of University of La Laguna, the different solutions that we have carried out from 2015, including the development of a technological tool for Moodle that allow the identification by teachers of the rights about content published into the virtual campus.
\end{abstract}

Key words

Intellectual property, author rights, higher education, virtual campuses, open access, open educational resources

\title{
1. Introduction
}

Internet has changed dramatically the way we access information and, as a consequence, the academic communication model. In this framework, the Open Access (OA) movement has been born with the aim to facilitate the free access to the academic information without technological barriers (Atkins et al, 2007; Daniel, 2011). However, the traditional way to spread the scientific knowledge is through private editorials (Springer, Elsevier, etc.). Therefore, universities have large contracts with platforms of scientific journals to access to their own research production. This situation is a concern for public institutions which has the obligation of transparency and openness of their production, especially those performed with public funding (Cairos et al, 2016).

At present, there is a strong political interest in the European Union (EU) towards Open Access. Since January 2016 the ministers of the EU are promoting the debate on Open Access, and, this issue is part of the European political agenda. In this sense, the European University Association (EUA), which the University of La Laguna is part, approved the development of a roadmap to help European universities in the transition to OA. The document proposes a set of objectives to promote the adoption of policies OA, addressing intellectual property rights and copyright policies, and to use and share scientific publications and research data, among others (Allen \& Seaman, 2014).

The University of La Laguna, as other many national and international universities, has been developed several actions to promote the open access to the knowledge produced by the institution (McAndrew \& Lane, 2010; Goodwin, 2011; Kernohan \& Thomas, 2012; Deimann \& Farrow, 2013; Fischer et al, 2015; Zancanaro et al, 2015). Some of this actions was the creation of the OpenCourseWare repository (http://ocw.ull.es) in 2008 or the platform of audiovisual educative pills ULLmedia (http://ullmedia.ull.es) in

The intellectual property of content published in virtual campuses: what legal and technological aspects should be considered?. Carina S. González-González, Luis Fajardo-López \& Dulce M. Cairós-Barreto. 
2010, both with Creative Commons licences. In 2014 was implanted the institutional repository RIULL (http://riull.ull.es) in order to open the access to $\mathrm{PhD}$ thesis, final master and degrees and scientific publications developed in the institution. The contents uploaded in all these repositories is under control of university's staff (librarians, virtual teaching unit, audiovisual service, etc.). Otherwise, the virtual campus (http://campusvirtual.ull.es) of the University of La Laguna, created in 2005 to support the learning-teaching model transition into the European Higher Education Area, can be considered nowadays as a large educational repository, holding millions of didactic resources produced by teachers and students. In the virtual campus, teachers can upload their contents and can open their virtual classrooms allowing the free access or not. The problem with the open access in the virtual campus is the control on the intellectual property resources uploaded by teachers. So, it is needed to design a set of actions in order to avoid legal issues with the management entities of intellectual property.

The aim of this work is to generate a proposal for a knowledge management policy which includes the Open Access university policy as one of its fundamental parts. This work will soon conclude with the formulation of the proposal to be adopted by the governing body of the ULL. So what we present here is not the decision of the university, but the proposition elaborated by the Open Access group of this institution. Nevertheless, it shows the content, the principles and tools for the university knowledge management policy in the framework of the conditioning guidelines that define the theses policies in Spain.

\section{Legal framework}

The management model of the intellectual property has been changing as a consequence of the new technologies. The University, as a defender of the creation of knowledge, must play a leading role in this evolution and so has it being done, as the response to the international challenge represented by the European Higher Education Area and the European Research Area. All this process has taken place under important legislative reforms which are the legal basis of the new policy. Spanish Law has not been unfamiliar to this evolution. It has experimented important changes during the last ten years and not without tensions and difficulties between laws coming from two ideologically different governments. Let's see the most important changes in our law:

\subsection{The obligation of the public universities to have institutional repositories (owned or shared).}

There were expected to be preferably free access with open standards and they should permit access to works of intellectual properties from anyone who apply for and not only from the Administration involved. The terms in which works can be public may be similar to a CC BY-ND-SA licence or more commonly CC BY-NC-ND-SA. Public Universities can organize shared repositories, buy private ones are not required to have any. Repositories of the public agents of the Spanish Science, Technology and Innovation System must have a centralized access and must be connected with similar national and international initiatives. Nowadays they are part of the Recolecta network (http://recolecta.fecyt.es/), which in its turn is part of the European network OpenAire (https://www.openaire.eu/).

It is framework, note the following issues:

The intellectual property of content published in virtual campuses: what legal and technological aspects should be considered?. Carina S. González-González, Luis Fajardo-López \& Dulce M. Cairós-Barreto. 
- In 2006 the Intellectual Property Act introduced a mandate to the Government to foster the creation of telematic public interest spaces for everyone (they were not still called repositories), open access and preferably free and universally available for digital works which were in the public domain, for public ownership works susceptible to be incorporated to that regime and for every work whose author expressly states that (D. A. $3^{\text {a }}$ Ley 23/2006, 7 July).

- The Act for the development of the information society (Ley 56/2007, 28 Dec.) compels all Public Administrations to make available to the public their digital production if it does not undermine their normal functioning and efficiency and does not affect public or general interest (D. A. 16 ${ }^{\mathrm{a}}$ ). It will be done on the internet and for the purposes of copying, studying and redistribution. The works must be distributed by the same way and the author must be quoted (similar to CC BY-ND-SA and CC BY-NC-ND-SA licence).

- Art. 37.1 and 5 of Science, Technology and Innovation Act (Ley 14/2011, 1 June) compels all public agents of the Science, Technology and Innovation Spanish system to foster open access repositories (owned or shared) for the publications of their research staff, setting up the connection with other national or international similar initiatives, under the support of the Ministry of Science and Innovation.

- It does not mean that these repositories must be open, but it is a kind of promotion of that type of publication. The universities are the ones which can manage the level of openness in searching competitiveness and excellence. The openness could be referred to researching centres reciprocally.

- The CRUE (Conference of Spanish Universities' Rectors) has coordinated that legislative mandate through REBUIN (University Libraries Spanish Network). The interoperability of all repositories is guaranteed by good practices assumed by all University Libraries and they count with the financial support of FECYT (Spanish Foundation for Science and Technology) to create the portal site Recolecta, which is part of OpenAire. The connection follows standard OAI$\mathrm{PMH}$.

\subsection{The obligation of researchers to publish their works openly if they have had funding coming from the General State Budget}

The Art. 37, 2 and 3 of the Science Act establishes that all publications resulting from mainly publicly funded research must have a digital copy of their final version, once they have been accepted to be published in periodical or serial research publications and a period of distraint of a maximum of 12 months may be accepted. This digital copy may be incorporated to well-known repositories of its area or to open access institutional repositories.

The Art. 37.4 of the Science Act indicates that this electronic version may be used by Public Administrations in their evaluation proceedings. In the end this will lead to encourage institutional repositories as the technological and organizational support of many new scientific journals of Universities and scientific areas. According to that we can mention the quality label for scientific collections CEA-APQ (Calidad en Edición Académica - Academic Publishing Quality), promoted by UNE and endorsed by ANECA and FECYT. All of that allows that some of the content of the institutional

The intellectual property of content published in virtual campuses: what legal and technological aspects should be considered?. Carina S. González-González, Luis Fajardo-López \& Dulce M. Cairós-Barreto. 
repository, the one which have a coincidence with journals with that label, must be recognized as evaluable merit. The Spanish Law doesn't seem to be ready to enforce that the evaluation of peer review works must be done with the module developed under the leadership of OpenScholars, although there is not any legal prohibition to use it.

\subsection{The right to the financial exploitation of every intellectual property resulting from the staff's work in the performance of his or her duties belongs to the University.}

This rule was introduced by the Universities Law (Organic Law 6/2001), the Science Law (Ley 14/2011) and it has been also introduced by the Sustainable Economy Law (Ley 2/2011, arts. 53 y 54), where we can see their most clear and overwhelming expression. The practice up to that date was to consider that the copyright belonged to the researcher, as it occurs in many European countries, even though art. 51 of our Intellectual Property Law states that the employer keep the royalties, in the absence of written agreement to the contrary.

\subsection{The obligation to publish openly all creations performed in the Universities.}

Wherever the research was financed by public budget or not, if the creation is generated in the framework of a public university, and it is just because it involves a Public Administration and we have to implement D. A. $16^{\mathrm{a}}$ of the Law on the Information Society. That Law compelled Public Administrations to make available all their digital content, including the production of University staff.

\subsection{The claim for payment sent to the Universities by a copyright collecting society (CEDRO) for the use of creations and works with teaching purposes.}

The copyright collecting societies and CEDRO (the one which have an impact in the university activities) didn't gather the digital exploitations rights from the authors, so they couldn't claim in this regard. When they began to do that a number of problems came up. This is the background information:

- The intellectual patrimony of Universities is the biggest patrimony which has not been incorporated to public domain by the running of the period to exercise the exploitation of intellectual property rights.

- To defend all its patrimony the Universities have joined the society that manages this intellectual patrimony (Centro Español de Derechos Reprográficos, CEDRO), in an early stage just to transfer the creations published by their publication services, which are just a little part of the intellectual patrimony of the Spanish universities. Spanish legislation is very clear in relation to royalties derived from works and creations of the university's researchers and teachers in the performance of their duties ${ }^{4}$.

Universities have tried to reformulate the claims in more concrete terms: to pay just for the use of protected content and not using a charge for every student. CEDRO sued several universities, but some agreements were reached before higher courts reached a

The intellectual property of content published in virtual campuses: what legal and technological aspects should be considered?. Carina S. González-González, Luis Fajardo-López \& Dulce M. Cairós-Barreto. 
final decision, so no general or theoretic judicial pronouncement has been obtained. In 2016, CEDRO and CRUE (in representation of 74 Spanish universities), signed an agreement of the 3 millions of euros by year, to facilitate the payment of authors rights by the use of books and other publications uploaded in the virtual campuses. This agreement is valid during two years, extendible one year more. After that, the entities has to renegotiate again the conditions.

\subsection{A new restrictive regulation related to teaching, which is likely contrary to European and Spanish Law, has been adopted and institutes a new charge for teaching usage.}

Until this new regulation (Ley 21/2014), there was no obligation to pay a fair compensation for the teaching usage of a creation. But now, and since 5 November 2015 , Universities must pay a charge for teaching usage, except otherwise provided in a written agreement with the right holder. It must be reminded that the exception or limitation for the sole purpose of illustration for teaching has been stated by art. 5.3 of Directive 2001/29/CE of the European Parliament and of the Council, of 22 May 2001, on the harmonisation of certain aspects of copyright and related rights in the information society, as well as by art. 10. 2 of Berne Convention for the Protection of Literary and Artistic Works, which refers to a fair practice. To consider that the fair practice is up to $10 \%$ maximum likely infringes the international treaties to which Spain is part, the European law and the Spanish Constitution. The new art. 32 of the Spanish Intellectual Property Law, related to the exception to the author's right in the cases of citations, reviews and illustration for teaching purposes or scientific research. What the part in bold-type means is that all the collective management societies (CEDRO in our case) have been entitled to the right to collect a canon, not for their repertory, but in a general manner, for every author, regardless whether they are associated to the collective society or not. In addition to that, CEDRO proposes to collect a fixed fee or flat rate (what they call CORSA index), based on its lack of knowledge of the works used and the authors affected. If the works and creations were identified, the authors could reclaim from CEDRO their rights and that would lead to a diminishment in CEDRO's annual accounts. The worse of it all is that in this time of budget cuts Universities have been forced to face very important allegedly payment obligations, which are not only unfair but also have an effect in terms of lack of full integration into the European Higher Education Area and the European Research Area, in the framework of the open access policies which constitutes nowadays a legal requirement for all the Public Administrations.

The interpretation of the exception for illustration for teaching and scientific research is questionable, especially the criteria to which it is referred (the reproduction must be limited to a maximum of a chapter of a book, a paper in a scientific journal or equivalent work of equivalent extension in an assimilated publication, or an extension up to $10 \%$ of the complete work), which must be considered as illustrative criterion but never the only possible exercise of the "fair practice". This is note the interpretation used and divulged by the collective management societies of intellectual property rights, especially by CEDRO in the Spanish case, but we think that it is the appropriate one. This is the scenario in which CEDRO sued the University of La Laguna (and some other Universities) as a preparatory step to propose a framework agreement between

The intellectual property of content published in virtual campuses: what legal and technological aspects should be considered?. Carina S. González-González, Luis Fajardo-López \& Dulce M. Cairós-Barreto. 
CEDRO-VEGAP and CRUE with two main objectives: to reach an agreement in order to state the obligation of the universities to pay canon for the teaching usage of works protected by royalties and to force the Universities to design a tool to measure the usage made by the university community of the works and creations incorporated to the virtual campus. Nowadays, the agreement between CEDRO-VEGAP and CRUE is signed and valid until 2018.

\subsection{The conflict between CEDRO and the University of La Laguna}

On 30 July 2015, just before the summer closure of the University, CEDRO presented a complaint to the University of La Laguna in which CEDRO accused ULL of scanning protected works and making them available in the virtual campus at least during the academic years 2013-14 and 2014-15", so University was violating the exclusive intellectual property rights. CEDRO added that the configuration of the virtual campus allowed that verification because no password was needed, the content was open. There was no indication or evidence of the infraction, there was no identification of the victims, the authors whose royalties have been violated, nor the scanned works and its incorporation to the repertory represented by CEDRO, there was no quantification of the damages. CEDRO claimed 5 euros per full time student, which is not connected with the effective utilization of the protected content.

In the following section it is present the actions developed by the University of La Laguna to promote the open access and to lock after the intellectual property gin their virtual campus.

The intellectual property of content published in virtual campuses: what legal and technological aspects should be considered?. Carina S. González-González, Luis Fajardo-López \& Dulce M. Cairós-Barreto. 


\section{The University of La Laguna's case}

\subsection{Virtual campus and intellectual property}

The University of La Laguna, through the Virtual Teaching Unit, has been making important efforts in order to ensure the enforcement of the intellectual property laws, such as:

a) Since 2005, the Virtual Teaching Unit (UDV) assesses practices used in the virtual campus, identifying good practices and reporting their results in its webpage (http://udv.ull.es/portal/category/observatorio-de-innovacioneducativa/). Periodically, if some infraction to intellectual rights is found in the virtual classrooms, teachers are warned.

b) Since 2007, the UDV includes in its training programme some courses on open access licences, some workshops have been organized and when some content has been suspected to infringe intellectual property rights, teachers and other people involved have been warned.

c) The virtual campus of the ULL has a "terms and conditions" document with information concerning intellectual property rights, which is visible in the virtual campus. Users has to accept it to have access to every virtual space of the virtual campus.

d) There is a protocol to publish didactic materials in the virtual campus available in the "help and support" section of the virtual campus (Figure 1).

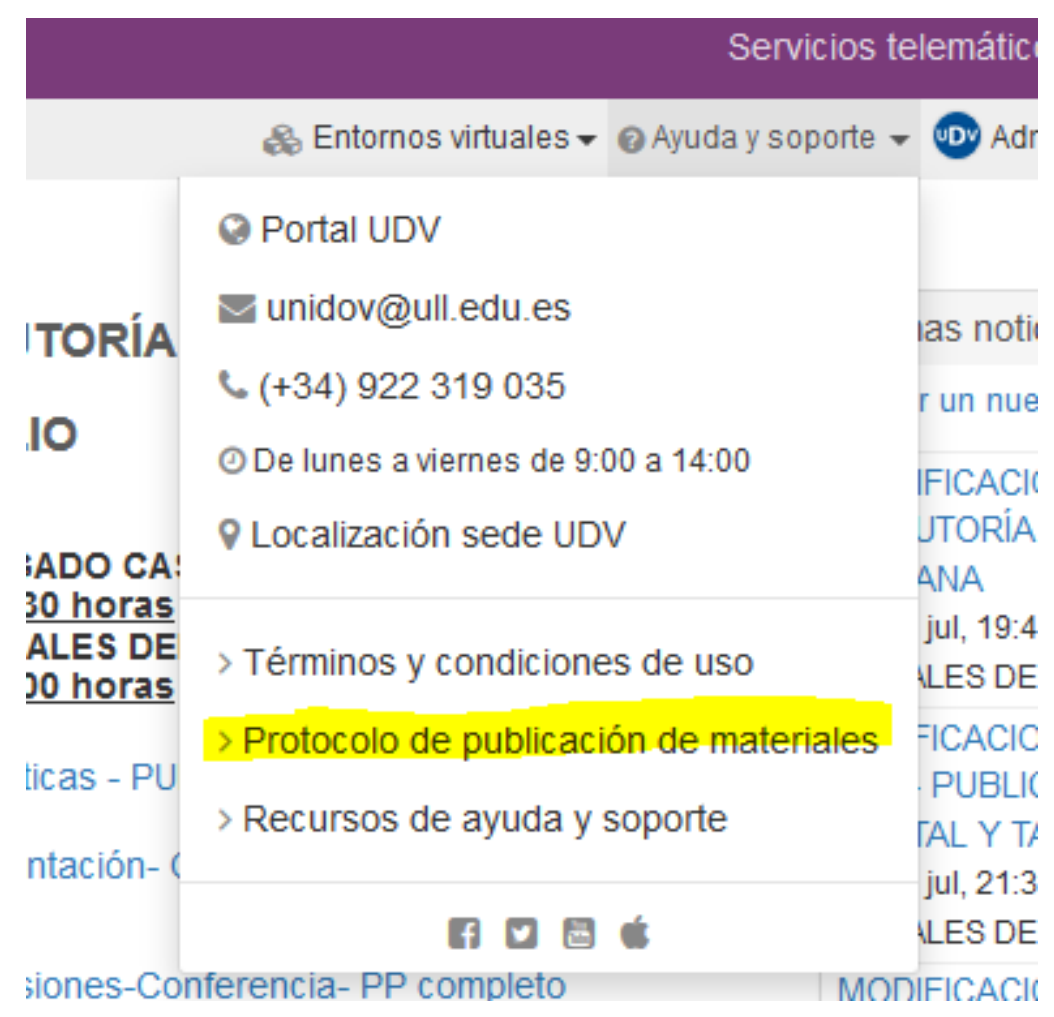

The intellectual property of content published in virtual campuses: what legal and technological aspects should be considered?. Carina S. González-González, Luis Fajardo-López \& Dulce M. Cairós-Barreto. 
Figure 1. Protocol to publish didactic materials in the virtual campus of ULL

A complete contents analysis of the two demanded campuses by CEDRO (2013-14 and 2014-15) has been made. The analysis, despite its complexity due to the volume of data, has been analyzed manually. Note the virtual campus of the above courses are no longer available / accessible to teachers and the assignment of teachers to virtual classrooms change from a course to another under the Plan for Academic. In particular, we presented the results of the analysis regarding the open access classrooms, which has the guest access option enable (Table 1).

\section{3-14}

Total of institutional virtual classrooms Total of open access virtual classrooms $\%$ open access virtual classrooms Media of students by virtual classroom

5356
95
$1,77 \%$
56,6
55,5

Table 1. Results corresponding to 2013-2014 and 2014-2015 academic years.

With the analysis that has been done can not be said that it is against a background of widespread copying but rather the opposite. The analysis shows that the vast majority of the material used in the virtual classrooms is prepared by the own teachers. What can be said is that, in any case, the percentage of work that can not ensure that its use is legitimate is related $4 \%$. In other words, $96 \%$ of the works are legitimately used.

To the versión of 2015-16 virtual campus it has been developed an informatic solution which allow teachers the easy identification the licences and intellectual property of their resources in the virtual classrooms. This solution developed as a plugin of Moodle and incorporated in the virtual classroom as a block, follows the legal framework with the educational exceptions described previously. So, this software development and subsequent deployment have required the assistance of library services, as well as the relevant legal advice, for the drafting of legal supposeds on the type of licenses.

The intellectual property of content published in virtual campuses: what legal and technological aspects should be considered?. Carina S. González-González, Luis Fajardo-López \& Dulce M. Cairós-Barreto. 


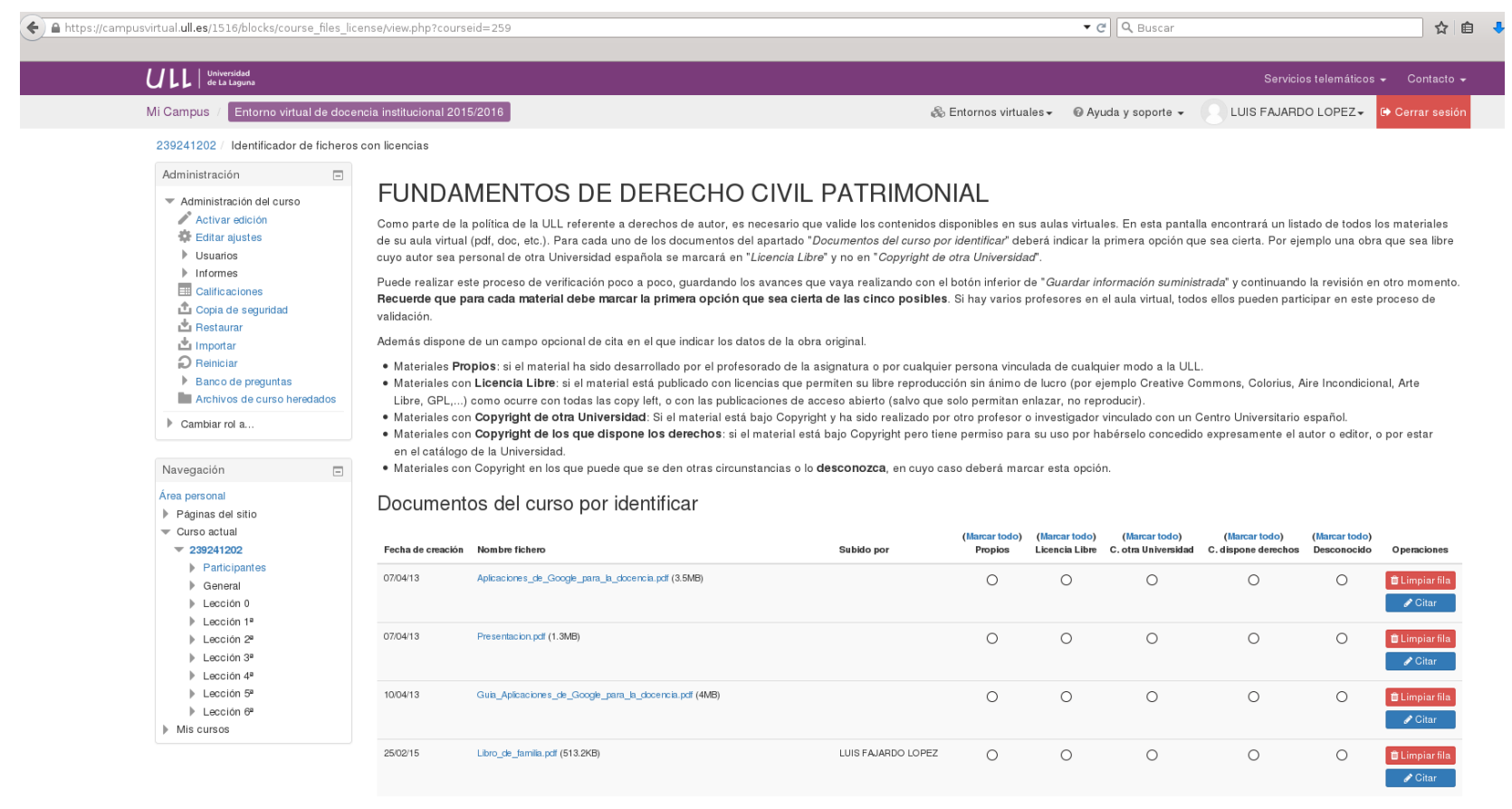

Figure 2. Plugin developed for Moodle. Activated in the 2015-16 virtual campus.

A survey was carried on using this plugin during the second semester of the last academic year. Results are presented in Table 2 and Figure 3.

\begin{tabular}{|c|c|c|}
\hline $\begin{array}{l}\text { Type of } \\
\text { licence }\end{array}$ & Description & $\mathbf{N}^{\mathbf{0}}$ files \\
\hline Own & $\begin{array}{l}\text { Own resource: if the resource has been developed by teachers of } \\
\text { the subject or any person connected in any way to the ULL. }\end{array}$ & 1137 \\
\hline Free License & $\begin{array}{l}\text { Free Licensed resource: If the resource is published under } \\
\text { licenses that allow free nonprofit reproduction (eg Creative } \\
\text { Commons, Colorius, Unconditional Air, Free Art, GPL, ...) as } \\
\text { with every copy left, or with open access publishing (except } \\
\text { that only allow single link, not play). }\end{array}$ & 283 \\
\hline $\begin{array}{l}\text { C. other } \\
\text { University }\end{array}$ & $\begin{array}{l}\text { Copyrighted resources by other University: If the resource is } \\
\text { not under a free license (ie, have Copyright) and has been } \\
\text { linked carried out by staff with a Spanish University or } \\
\text { Research Center. }\end{array}$ & 14 \\
\hline $\begin{array}{l}\text { C. which has } \\
\text { rights }\end{array}$ & $\begin{array}{l}\text { Copyright of resources with available rights: if the resource is } \\
\text { under Copyright but have permission to use haberselo expressly } \\
\text { granted by the author or publisher, or being in the catalog of the } \\
\text { University. }\end{array}$ & 46 \\
\hline $\begin{array}{l}\text { Unknown / } \\
\text { Teaching } \\
\text { Use }\end{array}$ & $\begin{array}{l}\text { Copyright in resources that may be given other circumstances } \\
\text { (for example, meet the requirements for teaching purposes of } \\
\text { Article } 32 \text {, paragraphs } 3 \text { and } 4 \text { of the Law on Intellectual } \\
\text { Property) or unknown, in which case you should check this } \\
\text { option. }\end{array}$ & 319 \\
\hline
\end{tabular}

Table 2. Results of the survey to teachers through Moodle plugin developed for the 2015-2016 Virtual Campus .

The intellectual property of content published in virtual campuses: what legal and technological aspects should be considered?. Carina S. González-González, Luis Fajardo-López \& Dulce M. Cairós-Barreto. 


\section{Types of licences in the virtual campus (2015-2016)}

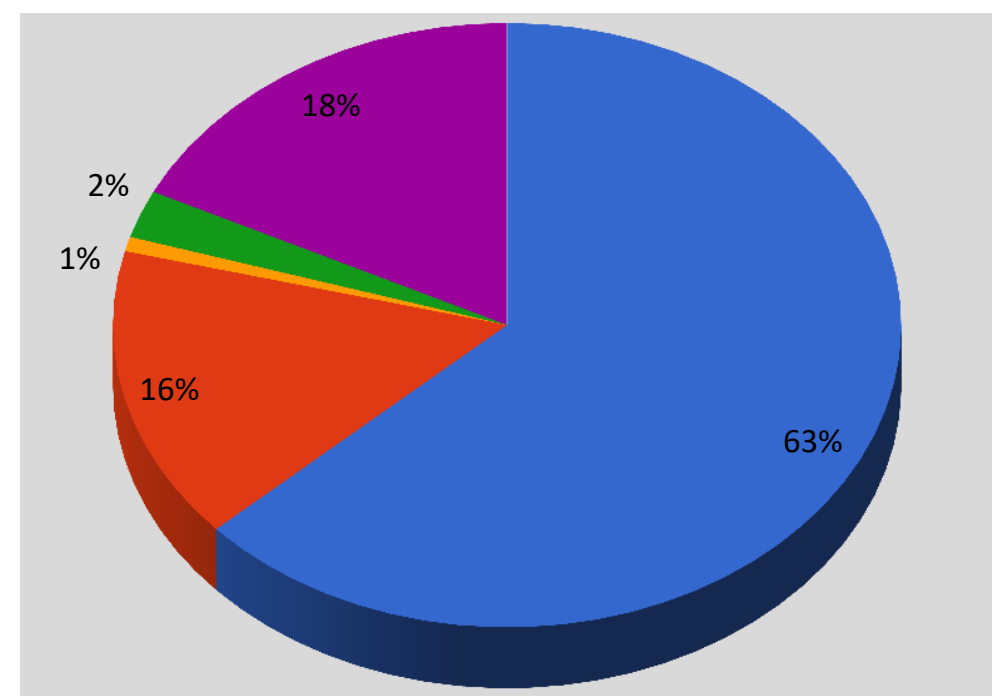

Own

Free Licence

C. other University

- C. rights availables

- Unknown/Teaching Use

Figure 3. Results of survey made with the plugin on the Virtual Campus (2015-16).

Results show that only $17.73 \%$ of educational resources are copyrighted materials in which may be given other circumstances (for example, meet the requirements for teaching purposes of Article 32, paragraphs 3 and 4 of the intellectual property law) or whose license is unknown by teacher. As in the previous analysis of virtual campuses, there is a high percentage of resources created by the own teachers $(63 \%)$ and with free licences $(16 \%)$.

\subsection{Promoting Open Access in Educational Contents}

Currently, as we can see above, the Virtual Campus centralizes the academic offer of the ULL in a single access portal, and in this way virtual support is offered to all its degrees. However, the University of La Laguna has other technological tools and services that support innovation in teaching. This is the case of ULLMEDIA, created in 2009 to support the production of audiovisual content for educational and research purposes. This support made by ULLMEDIA to educational innovation is carried out through different calls, including from the 2010-2011 academic year as part of the thematic blocks (multimedia learning objects, digital didactic materials (MDD)). Other calls has been related with the open content creation, such as MOOCs and OCW. On the other hand, ULLMEDIA promotes the creation of knowledge in open, since its contents are published under Creative Commons licenses.

In order to promote the creation of open educational resources and, at the same time, protect the academic knwolege production a call for proposals has been launched in

The intellectual property of content published in virtual campuses: what legal and technological aspects should be considered?. Carina S. González-González, Luis Fajardo-López \& Dulce M. Cairós-Barreto. 
$2017^{1}$. This call tends to promote the creation of open quality educational content and its publication in the Institutional Repository of the ULL (RIULL). This strategy of educational innovation is, at the same time, of open knowledge management. Likewise, it seeks to promote the quality of the educational contents of the ULL Virtual Campus (http://campusvirtual.ull.es) and the quality of the educational contents of the ULLMEDIA channel, recognizing the authorship of didactic materials to obtain educational merits. Finally, this call tries to change the university culture on the protection of the contents, taking steps towards the opening of university knowledge in the network.

\section{Conclusions}

It is difficult reconcile the obligation to public openly, according to the Spanish Science Law (Ley 14/2011), with the enforcement of new art. 32 Intellectual Law Act (currently it must consist of the defence of the right to illustration for teaching purposes with no fair compensation).

Moreover, it is needed to elaborate and to approve a knowledge management policy which make clear the terms for publishing and the ways in which the exploitation of the intellectual property rights can be done. Coordination with other Universities and Research Centres must be guaranteed. At the Spanish level there is a tool, named MELIBEA project (similar to SHERPA/ROMEO), which is a kind of open access repository of different editors and institutions. All the university intellectual patrimony must be incorporated to the institutional repository and the University must define the scope of the decision of the authors, facilitating a number of licences and actuation protocols to allow the publication outside the University.

Also, it is necessary to strengthen the ICT services which support the knowledge management policy, such as open repositories and electronic procedures. ULL counts on its own repository incorporated to Recolecta. However, the structure was not developed enough to make a distinction related to the level of access. Unified management of the intellectual property, connecting the library services with the virtual campus and the open repository is highly recommended. Some technical improvements in the repository can foster the open access, for instance, the creation of a platform to edit documents or the connection with editors and supply platforms (Etherpad and similar), peer-review from the repository (such as Open Peer Review Module for Repositories) or the integration of social networks; measures to foster the utilization of well-structured texts; creation of contributory teaching books and materials, which can develop with the contribution of several persons so they can be easily updated.

It must be an agreement according to law, understanding the position of the Universities and in line with their social function. Thus, all the universities should sign an agreement to avoid the application of art. 32.4 Intellectual Property Law in its current configuration regarding to the payment of the canon for the utilization of other Universities' materials, just by the mere reciprocal authorization in the framework of the interconnection of their institutional repositories.

\footnotetext{
${ }^{1}$ Call for Open Didatic Digital Resources at University of La Laguna: https://www.ull.es/Private/folder/institucional/ull/wull/estudios_docencia/udv/convoabiertamdd.pdf
}

The intellectual property of content published in virtual campuses: what legal and technological aspects should be considered?. Carina S. González-González, Luis Fajardo-López \& Dulce M. Cairós-Barreto. 
Regarding the intellectual property of educational resources published in virtual campuses, as have been shown in the case of University the La Laguna, the resources are created mainly by teachers, and their production belong to the University. And in the rest of the cases, resources has free licences or belong to other universities. The institutional repositories, together with the on line bibliographic resources, should be the technological base for the knowledge management through inter-university transfer agreements and for the respect to the intellectual property rights in the university sector. The technological integration of the repositories through Recolecta and OpenAir projects must be strengthen with legal exchange agreements. So not only open access content could be accessible, but also some other content covered under some protocols of mutual exchange and related to university content initially not open. There must be also economic compensation settlements between universities. And agreements with editor must be explored as well. The idea is to reach previous settlements with authors and editors and to try to avoid the canon in favour of the copyright collective management societies. All that is possible, but we have to combine the institutional repositories and library services with adequate technological development of the electronic government. For instance, in the ULL all this service integration has been developed in the so called "Q Point". The informatics services are currently working on a way to avoid the incorporation of materials outside the institutional repository and its utilization outside the $\mathrm{Q}$ point. Access to the repository must be monitored by an egovernment procedure, so the identity of users must be guaranteed. At the same time the authorship can be ensured and the University promotes the knowledge of its own production.

Moreover, a knowledge management policy must develop an opinion about scientific social networks, giving instructions for their utilization and analysing those similar to SHERPA/ROMEO, in order to classifying them according to the institutional policies. Finally, note that the growth of Open Education has led many European universities to reconsider their institutional strategies, added the pressure to innovate in teaching and learning practices, in order not to lose their competitive advantage. However, many issues that accompany the integration of new learning formats into higher education have not yet been addressed satisfactorily, such as:

- How to validate and recognize the skills acquired by students?

- How to reconcile and combine new learning formats with established mechanisms and operating strategies?

- How universities can open their institutions effectively to further improve the quality and relevance of their educational offer?

- What kind of accompanying policy mechanisms can help universities in this process of innovation and modernization?

The work presented in this paper tends to contribute to give some legal guidelines and technological tools, based in the experience, to promote effectively the Open Education in universities.

The intellectual property of content published in virtual campuses: what legal and technological aspects should be considered?. Carina S. González-González, Luis Fajardo-López \& Dulce M. Cairós-Barreto. 
Presentación del artículo: 15 de febrero de 2017 Fecha de aprobación: 6 de marzo de 2017 Fecha de publicación: 31 de marzo de 2017

González-González, C. S., Fajardo-López, L. y Cairós-Barreto, D. M. (2017). The intellectual property of content published in virtual campuses: what legal and technological aspects should be considered?. RED. Revista de Educación a Distancia, 53. Consultado el (dd/mm/aaaa) en http://www.um.es/ead/red/

\section{References}

Allen, I. E. \& Seaman, J. (2014). Opening the curriculum: Open educational resources in U.S. higher education. Retrieved from http://www.onlinelearningsurvey.com/reports/openingthecurriculum2014.pdf

Atkins, D.E., Brown, J.S. \& Hammond, A.L. (February 2007). A review of the Open Education Resources (OER) Movement: Achievements, Challenges and New Opportunities. Report to The William and Flora Hewlett Foundation. Retrieved from: http://www.hewlett.org/uploads/files/ReviewoftheOERMovement.pdf

Berlin Declaration on Open Access to Knowledge in the Sciences and Humanities, 2003. Retrieved on 1 Sep 2016 from http://openaccess.mpg.de/286432/BerlinDeclaration. See also Signatories of the Berlin Declaration.

Cairos D., Fajardo L., González C. S.,2016. Towards effective institutional policies to promote open access in educational resources. Workpaper. Retrieved on 1 Sep 2016 from http://riull.ull.es/xmlui/handle/915/2120

Creative Commons (n.d.). About page. Retrieved from http://creativecommons.org/about

Daniel, J. (2011). Open but tough. OER Foundation consultative meeting for the OER university concept. 23 February 2011, Dunedin, New Zealand. Retrieved from: http://www.col.org/resources/speeches/2011presentation/Pages/2011-02-23.aspx

Deimann, M., \& Farrow, R. (2013). Rethinking OER and their use: Open education as Bildung. International Review of Research in Open and Distributed Learning, 14(3), 344-360.

Documentation of Pasteur4OA - Regional Workshop for Research Performing Organisations of SW Europe countries "Working Together to Promote Open Access Policy Alignment in Europe" (Torino 22 February 2016). Retrieved on 1 Sep 2016 from http://www.pasteur4oa.eu/events/161\#.Vt1UXvmLRqw

EUA Roadmap on Open Access to Resarch Publications (2016). Retrieved on 1 Sep 2016 from http://eua.be/Libraries/publications-homepage-list/eua-roadmap-onopen-access-to-research-publications.

Fischer, L., Hilton III, J., Robinson, T. J., \& Wiley, D. (2015). A multi-institutional study of the impact of open textbook adoption on the learning outcomes of

The intellectual property of content published in virtual campuses: what legal and technological aspects should be considered?. Carina S. González-González, Luis Fajardo-López \& Dulce M. Cairós-Barreto. 
postsecondary students. Journal of Computing in Higher Education, 27, 159 172.

Institute of Educational Technology, Open University U.K. (n.d.). OER impact map. Retrieved from http://oermap.org/open-education-timeline/

Kernohan, D., \& Thomas, A. (2012, October). Open educational resources - A historical perspective. Paper presented at ALTC2012: A confrontation with reality, Manchester, UK. Retrieved from http://repository.jisc.ac.uk/4915/

Lund Goodwin, M. A. (2011). The open course library: Using open educational resources to improve community college access. Doctoral Dissertation retrieved from https://research.wsulibs.wsu.edu/xmlui/bitstream/handle/2376/3497/Goodwin_w su_0251E_10286.pdf? sequence $=1$

McAndrew, P. \& Lane, A. (2010). The impact of OpenLearn: making The Open University more "open", Association for Learning and Technology online newsletter, Issue 18, Friday 15th January 2010, ISSN 1748-3603. Retrieved from: http://newsletter.alt.ac.uk/4ii7jyi4jnx

Open Education (OpenEdu). European Comission. Fuente: http://is.jrc.ec.europa.eu/pages/EAP/OpenEdu.html

Open Education Consortium (n.d.) About us. Retrieved from http://www.oeconsortium.org/about-oec/

Schimmer R., ,Geschuhn K.,Vogler A. (2015). Disrupting the subscription journals' business model for the necessary large-scale transformation to open access, http://dx.doi.org/10.17617/1.3. Retrieved on 1 Sep 2016 from http://pubman.mpdl.mpg.de/pubman/item/escidoc:2148961:7/component/escido c:2149096/MPDL_OA-Transition_White_Paper.pdf

WikiEducator (2011). An intellectual property policy for our times. Retrieved from: http://wikieducator.org/Otago_Polytechnic:_An_IP_policy for the times

Zancanaro, A., Todesco, J. L., \& Ramos, F. (2015). A bibliometric mapping of open educational resources. International Review of Research in Open and Distributed Learning, 14(3), 344-360.

The intellectual property of content published in virtual campuses: what legal and technological aspects should be considered?. Carina S. González-González, Luis Fajardo-López \& Dulce M. Cairós-Barreto. 